\title{
Research Letter \\ Effect of Incorporating Nanoporous Metal Phosphate Materials on the Compressive Strength of Portland Cement
}

\author{
Dawn M. Wellman, Kent E. Parker, Shas V. Mattigod, and Glen E. Fryxell \\ The Pacific Northwest National Laboratory, P.O. Box 999, K3-62 Richland, WA 99352, USA \\ Correspondence should be addressed to Dawn M. Wellman, dawn.wellman@pnl.gov
}

Received 12 December 2007; Accepted 27 February 2008

Recommended by Steven Suib

Nanoporous metal phosphate (NP-MPO) materials are being developed for removal of contaminant oxyanions $\left(\mathrm{As}(\mathrm{OH}) \mathrm{O}_{3}{ }^{2-}\right.$, $\mathrm{CrO}_{4}{ }^{2-}$, and $\mathrm{TcO}_{4}{ }^{-}$), and cations (mercury, cadmium, and lead) from water and waste streams. Following sequestration, incorporation of metal laden NP-MPOs as a portion of cement formulation would provide an efficient and low-cost way to immobilize metal laden NP-MPOs in an easily handled waste form suitable for permanent disposal. There are no known investigations regarding the incorporation of NP-MPOs in concrete and the effects imparted on the physical and mechanical properties of concrete. Results of this investigation demonstrated that incorporating of NP-MPO materials requires additional water in the concrete formulation which decreases the compressive strength. Thus, incorporation of NP-MPOs in concrete may not serve as an efficient means for long-term disposal.

Copyright (c) 2008 Dawn M. Wellman et al. This is an open access article distributed under the Creative Commons Attribution License, which permits unrestricted use, distribution, and reproduction in any medium, provided the original work is properly cited.

\section{INTRODUCTION}

Over the last decade, metal phosphate materials have been studied extensively for their potential use in catalysis, ion exchange, and phase separation $[1,2]$. In contrast to silicabased materials, functionality of metal phosphates is inherently present, and recent advancements enabling control of the redox state of the metal center allow the reductive capacity of the metal phosphate material to be controlled for redox sensitive ion sequestration [3]. Nanoporous metal phosphate (NP-MPO) materials are being developed for removal of contaminant oxyanions $\left(\mathrm{As}(\mathrm{OH}) \mathrm{O}_{3}{ }^{2-}, \mathrm{CrO}_{4}{ }^{2-}\right.$, and $\mathrm{TcO}_{4}{ }^{-}$) [3] and cations (mercury, cadmium, and lead), respectively, from water and various waste streams. Nanoporous materials offer an efficient way of selectively sequestering many types of metals and radionuclides in a very small volume [4-10]. The high surface area of a nanoporous structure enhances mass transfer in sequestration applications and enables ions to be highly concentrated in a very small volume of material. Following sequestration, incorporation of contaminant laden NP-MPOs as a portion of cement formulation would provide an efficient, low-cost method to immobilize waste NP-MPOs in situ and would contain it in an easily handled waste form suitable for permanent disposal.
Concrete stabilization is a process of mixing waste with a binder to reduce the contaminant leachability by both physical and chemical means and to convert hazardous waste into environmentally acceptable waste forms for disposal [11]. Cement is widely used for stabilization of hazardous, radioactive, and mixed wastes [12] which serves to contain and isolate the waste from the hydrologic environment and to act as an intrusion barrier. Any failure of concrete stabilization may result in water intrusion and consequent mobilization of contaminants from the waste packages by mass flow and/or diffusion and may move into the surrounding subsurface environment.

Portland cement is the most commonly utilized cement because of its availability and low cost. Additional materials such as fly ash, natural pozzolans, and blast furnace slag often supplement the cement matrix which reduces cost and improves the performance of the concrete. Pozzolanic and mineral admixtures have previously been studied with regards to the effects imparted on the physical and mechanical properties of concrete $[13,14]$. However, incorporating advanced materials such as nanoporous metal phosphate materials in concrete and their effect on the chemical, physical, and mechanical properties of concrete waste forms have not been investigated. 
Compressive strength is generally accepted as a principal measure of the quality of concrete, with approximate relations between compressive strength and other mechanical properties of concrete [15]. The objective of this investigation was to evaluate mixture proportions for incorporation of NP-MPOs in Portland cement and to quantify its effects on compressive strength of the resulting concrete monolith.

\section{MATERIALS AND METHODS}

The concrete composition used for this study was based on the mixture composition specified for encasing low-level radioactive waste [15]. This specification was used as the basis to prepare a concrete for fabrication of test specimens. The specified composition includes sulfate-resistant Portland Type I or Type II cement, a pozzolanic material (Class F fly ash), fine and coarse aggregates, and steel fiber. Table 1 (column 3) presents the mixture composition specified for encasing low-level radioactive waste [15]. Table 1 (column 4) presents the mass normalized composition for encasing lowlevel radioactive waste; Table 1 (column 6) provides the mass normalized composition for the laboratory concrete composition.

A laboratory-scale concrete mixture was prepared based on field-scale specifications to prepare concrete for waste immobilization (Table 1). Because of the required small dimensions of laboratory test specimens, iron particles $(-40$ to +60 mesh) were used as the scaled-down steel fibers. A particle size $<2 \mathrm{~mm}$ was used as the aggregate in the laboratory composition. Based on these modifications, a concrete mix was prepared that consisted of Portland cement (Type I and II, ASTM C-150 compliant), Class F fly ash, scaled-down coarse aggregate, fine aggregate, iron particles, and a waterentraining agent (Polyheed 997). The water-entraining agent was included in the mix to facilitate the workability of the concrete.

Concrete monoliths were prepared with components added in the order: cement, fly ash, coarse aggregate, steel (if applicable), NP-MPO (if applicable), Polyheed 997, MB AE 90, and water (Table 1). The concrete was mixed in polypropylene containers for five minutes to ensure homogeneity of the mixture. Polycarbonate bottles were used as the concrete molds for casting specimens. The molds were filled in the vertical positions. After filling, the molds were vibrated and lightly tapped on the laboratory bench until a significant decrease in the release of air bubbles was observed. The forms were stored in a humidity chamber for 5 days at which time the concrete monoliths were removed from the molds. The monoliths were subsequently stored in the humidity chamber for 23 days for a total of 28 days, as specified in ASTM standard C109/C109M-02 [16]. Compression testing was conducted in accordance with ASTM procedure C109/C109M-02 using a Carver Laboratory Press (Model M).

\section{RESULTS AND DISCUSSION}

Table 2 presents the mass normalized composition and physical characteristics of the concrete specimens; Table 3 pro-

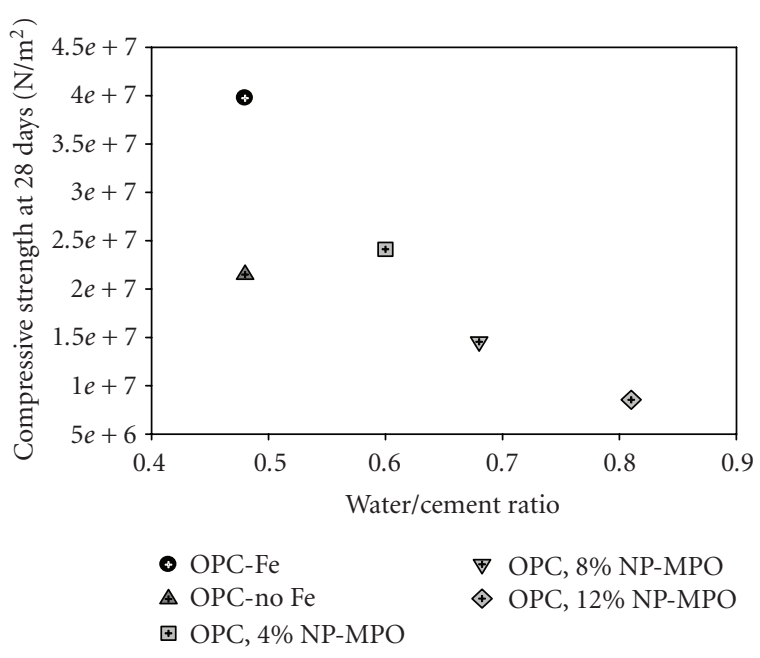

FIgURE 1: Compressive strength of Portland cement with and without iron and/or nanoporous metal phosphate materials as a function of water/cement ratio.

vides the calculated water/cement ratio and calculated compressive strength of the concrete monoliths. The water to cement ratio is the mass-based ratio of water to cement within the concrete composition. The compressive strength was calculated per ASTM procedure C109/C109M-02. The experimentally measured force (lbs) necessary to produce structural failure of the concrete specimens was used to calculate the respective force per unit surface area $\left(\mathrm{N} / \mathrm{m}^{2}\right)$ (Table 3$)$.

The contribution of steel or iron particles on the durability of concrete has long been practiced. The use of steel fibers increases the density and energy absorption capacity and reduces cracking by bridging microcracks within the concrete matrix among others [17-20]. Results presented in this investigation indicate that incorporating iron particles into the concrete matrix increases the bulk density by $\sim 6 \%$. Substituting NP-MPOs into the concrete matrix in place of iron particles decreases the bulk density of the concrete monolith by $\sim 1.5 \%$ for every $4 \%$ increase in NP-MPO.

Figure 1 illustrates the effect of incorporating nanoporous metal phosphate materials in Portland cement on the compressive strength. The results illustrate the inclusion of iron particles within the concrete monolith which affords a composition with the greatest compressive strength. Based on the water/cement ratio of the iron containing monolith, the calculated compressive strength is 0.7 times greater than standard concrete [21]. Removing iron particles from the concrete matrix decreased the compressive strength of the test core $\sim 45 \%$. Substituting $4 \%$ NP-MPOs into the concrete matrix in place of the iron particles afforded a $40 \%$ decrease in the compressive strength relative to the monolith containing iron. However, approximately a $10 \%$ increase in compressive strength was measured for the concrete monolith containing 4\% NP-MPO relative to the concrete monolith without iron or NP-MPO. Further increasing the content of NP-MPOs in the concrete matrix significantly decreased the compressive strength of concrete. 
TABLE 1: Material specifications and composition.

\begin{tabular}{|c|c|c|c|c|c|}
\hline Material & Specifications & $\begin{array}{l}\text { Specified field } \\
\text { composition }\end{array}$ & $\begin{array}{l}\text { Mass- } \\
\text { normalized field } \\
\text { specified } \\
\text { composition }\end{array}$ & $\begin{array}{l}\text { Material } \\
\text { specifications used } \\
\text { in revised } \\
\text { laboratory mix } \\
\text { comparison }\end{array}$ & $\begin{array}{l}\text { Mass-normalized } \\
\text { laboratory } \\
\text { composition }\end{array}$ \\
\hline Cement & $\begin{array}{l}\text { Portland Type I or } \\
\text { Type I/II } \\
\text { sulfate-resistant } \\
\text { cement }\end{array}$ & $381 \mathrm{~kg} / \mathrm{m}^{3}$ & 0.27 & $\begin{array}{l}\text { Portland Type I } \\
\text { and II }\end{array}$ & 0.27 \\
\hline Fly Ash & $\begin{array}{l}\text { Class F fly ash; } \\
\text { nominal } 15 \% \text { of } \\
\text { cement by volume }\end{array}$ & $54 \mathrm{~kg} / \mathrm{m}^{3}$ & 0.04 & $\begin{array}{l}\text { Class F fly ash; } \\
\text { nominal } 20 \% \text { of } \\
\text { cement by volume }\end{array}$ & 0.04 \\
\hline Coarse aggregate & $\begin{array}{l}\text { no. } 676 \text { or } \\
\text { equivalent ( } 3 / 4 " \\
\text { nominal size) }\end{array}$ & $55 \%$ by volume & 0.04 & - & - \\
\hline Fine Aggregate & Sand & $45 \%$ by volume & 0.51 & $<2 \mathrm{~mm}$ sand & 0.51 \\
\hline Water & $\begin{array}{l}\text { Nominal } \\
\text { water:cement ratio: } \\
0.4\end{array}$ & $399 \mathrm{~kg} / \mathrm{m}^{3}$ & 0.10 & $\begin{array}{l}\text { Water-to-cement } \\
\text { ratio: } 0.5\end{array}$ & 0.13 \\
\hline Steel Fiber & $\begin{array}{l}\text { Deformed Type I, } \\
\text { nominal length } \\
2.5-3.8 \mathrm{~cm}\left(1-1.5^{\prime \prime}\right)\end{array}$ & $59 \mathrm{~kg} / \mathrm{m}^{3}$ & 0.04 & $\begin{array}{l}\text { Iron Particles, } \\
-200 \text { mesh }\end{array}$ & 0.04 \\
\hline Air Content & - & $6.0 \pm 1.5 \%$ & - & - & $6.0 \pm 1.5 \%$ \\
\hline Polyheed 997 & - & - & - & $\begin{array}{l}\text { Water-entraining } \\
\text { agent }\end{array}$ & 0.007 \\
\hline
\end{tabular}

TABLE 2: Composition and physical characteristics of concrete specimens used in compression tests.

\begin{tabular}{|c|c|c|c|c|c|c|}
\hline Material & $\begin{array}{l}\text { Mass-normalized } \\
\text { laboratory } \\
\text { composition }\end{array}$ & $\begin{array}{l}\text { Mass- } \\
\text { normalized } \\
\text { composition: } \\
\text { Core } 1 \\
\end{array}$ & $\begin{array}{l}\text { Mass- } \\
\text { normalized } \\
\text { composition: } \\
\text { Core } 2 \\
\end{array}$ & $\begin{array}{l}\text { Mass- } \\
\text { normalized } \\
\text { composition: } \\
\text { Core } 3 \\
\end{array}$ & $\begin{array}{l}\text { Mass- } \\
\text { normalized } \\
\text { composition: } \\
\text { Core } 4 \\
\end{array}$ & $\begin{array}{l}\text { Mass } \\
\text { Normalized } \\
\text { Composition: } \\
\text { Core 5 } \\
\end{array}$ \\
\hline Cement & 0.27 & 0.29 & 0.29 & 0.28 & 0.28 & 0.27 \\
\hline Fly ash & 0.04 & 0.04 & 0.04 & 0.04 & 0.04 & 0.04 \\
\hline Fine aggregate & 0.51 & 0.47 & 0.51 & 0.46 & 0.41 & 0.36 \\
\hline Water & 0.10 & 0.14 & 0.14 & 0.17 & 0.19 & 0.22 \\
\hline Iron particles & 0.04 & 0.04 & - & - & - & - \\
\hline NP-MPO & - & - & - & 0.04 & 0.08 & 0.11 \\
\hline Polyheed 997 & 0.007 & 0.007 & 0.007 & 0.007 & 0.007 & 0.007 \\
\hline Air Content & $6.0 \pm 1.5 \%$ & $6.0 \pm 1.5 \%$ & $6.0 \pm 1.5 \%$ & $6.0 \pm 1.5 \%$ & $6.0 \pm 1.5 \%$ & $6.0 \pm 1.5 \%$ \\
\hline NP-MPO & 0.00 & 0.00 & 0.00 & 0.04 & 0.08 & 0.12 \\
\hline \multicolumn{7}{|c|}{ Physical characteristics } \\
\hline Length, $\mathrm{cm}$ & - & 4.17 & 4.35 & 4.41 & 4.62 & 4.62 \\
\hline Diameter, $\mathrm{cm}$ & - & 2.56 & 2.58 & 2.56 & 2.57 & 2.58 \\
\hline Surface area, $\mathrm{cm}^{2}$ & - & 42.71 & 44.25 & 44.60 & 46.12 & 46.32 \\
\hline Volume, $\mathrm{cm}^{3}$ & - & 20.59 & 21.57 & 21.78 & 22.70 & 22.86 \\
\hline Density, $\mathrm{g} / \mathrm{cm}^{3}$ & - & 2.21 & 2.08 & 2.06 & 2.02 & 1.99 \\
\hline
\end{tabular}

NP-MPOs are synthesized via surfactant-templated chemistry. In order to remove the surfactant from the porous structure, NP-MPOs were calcined at $\sim 500^{\circ} \mathrm{C}$. As a result, the materials are extremely dry, absorb a significant amount of water, and incorporation of them into the concrete ma- trix requires additional water to be added to the composition (Table 2). Thus, by increasing the proportion of NP-MPO incorporated into the concrete, the water/cement ratio of the concrete increases, which decreases the compressive strength of the concrete. 
TABLE 3: Compressive strength of concrete specimens.

\begin{tabular}{llll}
\hline Core no. & $\begin{array}{l}\text { Calculated } \\
\text { water/cement } \\
\text { ratio }\end{array}$ & $\begin{array}{l}\text { Force } \\
\text { (Newtons) }\end{array}$ & $\begin{array}{l}\text { Measured } \\
\text { compressive } \\
\text { strength }\left(\mathrm{N} / \mathrm{m}^{2}\right)\end{array}$ \\
\hline$(1)$ & 0.48 & 20461 & $3.97 \times 10^{7}$ \\
$(2)$ & 0.48 & 11120 & $2.15 \times 10^{7}$ \\
$(3)$ & 0.60 & 12454 & $2.41 \times 10^{7}$ \\
$(4)$ & 0.68 & 7562 & $1.46 \times 10^{7}$ \\
$(5)$ & 0.81 & 4448 & $8.55 \times 10^{6}$ \\
\hline
\end{tabular}

\section{CONCLUSION}

Incorporating metal laden NP-MPOs as a portion of cement formulation has been proposed as an efficient, low-cost, and low-temperature way to immobilize metal laden waste in situ and to contain it in an easily handled waste form suitable for permanent disposal. This investigation evaluated the effect of incorporating NP-MPOs in Portland cement formulations on the compressive strength of the concrete waste form. The results demonstrate the exceptionally dry nature of NP-MPO materials which requires the addition of extra water to the overall concrete formulation. This, in turn, increases the water/cement ratio and results in a decrease in the compressive strength of the concrete waste form. Thus, the incorporation of NP-MPOs in concrete may not serve as an efficient means for long-term disposal. In order for concrete stabilization to serve as a means for the long-term disposal of contaminant laden NP-MPOs, further investigation would be necessary to determine the optimal composition for incorporation.

\section{REFERENCES}

[1] S. Polarz and B. Smarsly, "Nanoporous materials," Journal of Nanoscience and Nanotechnology, vol. 2, no. 6, pp. 581-612, 2002.

[2] A. K. Cheetham, G. Férey, and T. Loiseau, "Open-framework inorganic materials," Angewandte Chemie International Edition, vol. 38, no. 22, pp. 3268-3292, 1999.

[3] D. M. Wellman, S. V. Mattigod, K. E. Parker, S. M. Heald, C. Wang, and G. E. Fryxell, "Synthesis of organically templated nanoporous tin(II/IV) phosphate for radionuclide and metal sequestration," Inorganic Chemistry, vol. 45, no. 6, pp. 23822384, 2006.

[4] G. E. Fryxell, J. Liu, A. A. Hauser, et al., "Design and synthesis of selective mesoporous anion traps," Chemistry of Materials, vol. 11, no. 8, pp. 2148-2154, 1999.

[5] G. E. Fryxell, J. Liu, and S. V. Mattigod, "Self-assembled monolayers on mesoporous supports (SAMMS) — an innovative environmental sorbent," Materials Technology, vol. 14, no. 4, pp. 188-191, 1999.

[6] S. V. Mattigod, X. Feng, G. E. Fryxell, J. Liu, and M. Gong, "Separation of complexed mercury from aqueous wastes using self-assembled mercaptan on mesoporous silica," Separation Science and Technology, vol. 34, no. 12, pp. 2329-2345, 1999.

[7] S. V. Mattigod, G. E. Fryxell, X. Feng, and J. Liu, "Selfassembled monolayers on mesoporous supports for metal separation," in Metal Separation Technologies Beyond 2000: Integrating Novel Chemistry with Processing, K. C. Liddell and D.
J. Chaiko, Eds., pp. 71-80, The Minerals, Metals \& Materials Society, Warrendale, Pa, USA, 1999.

[8] S. V. Mattigod, G. E. Fryxell, K. E. Parker, and Y. Lin, "Application of novel nanoporous sorbents for the removal of heavy metals, metalloids, and radionuclides," in Trace Elements in the Environment: Biogeochemistry, Biotechnology, and Bioremediation, M. N. V. Prasad, K. S. Sajwan, and R. Naidu, Eds., pp. 369-380, chapter 19, Taylor and Francis, Boca Raton, Fla, USA, 2005.

[9] S. V. Mattigod, G. E. Fryxell, R. J. Serne, and K. E. Parker, "Evaluation of novel getters for adsorption of radioiodine from ground water and waste glass leachates," Radiochimica Acta, vol. 91, no. 9, pp. 539-545, 2003.

[10] J. Liu, G. E. Fryxell, S. V. Mattigod, T. S. Zemanian, Y. Shin, and L.-Q. Wang, "Synthesis and applications of functionalized nanoporous materials for specific adsorption," in Nanoporoous Materials II, Studies in Surface Science and Catalysis, A. Sayari, M. Jaroniec, and T. J. Pinnavaia, Eds., vol. 129, pp. 729-738, Elsevier, Amsterdam, The Netherlands, 2000.

[11] R. Spence and C. Shi, Stabilization and Solidifcation of Hazardous, Radioactive, and Mixed Wastes, CRC Press, Boca Raton, Fla, USA, 2005.

[12] C. Shi, "Hydraulic cement systems for stabilization/solidification," in Stabilization and Solidification of Hazardous, Radioactive, and Mixed Wastes, R. Spence and C. Shi, Eds., pp. 49-78, chapter 4, CRC Press, Boca Raton, Fla, USA, 2005.

[13] Ş. Targan, A. Olgun, Y. Erdogan, and V. Sevinc, "Influence of natural pozzolan, colemanite ore waste, bottom ash, and fly ash on the properties of Portland cement," Cement and Concrete Research, vol. 33, no. 8, pp. 1175-1182, 2003.

[14] M. Cyr, P. Lawrence, and E. Ringot, "Efficiency of mineral admixtures in mortars: quantification of the physical and chemical effects of fine admixtures in relation with compressive strength," Cement and Concrete Research, vol. 36, no. 2, pp. 264-277, 2006.

[15] Specification for Concrete Encasement for Contact-Handled Category 3 Waste,Proceedings of Waste Management, 1998.

[16] ASTM C109/C109M-07, "Standard test method for compressive strength of hydraulic cement mortars (using 2 in. or [50 mm] cube specimens)," ASTM International, West Conshohocken, Pa, USA, 2002.

[17] J. Thomas and A. Ramaswamy, "Mechanical properties of steel fiber-reinforced concrete," Journal of Materials in Civil Engineering, vol. 19, no. 5, pp. 385-392, 2007.

[18] S. Ghosh, S. Bhattacharjya, and S. Chakraborty, "Compressive behaviour of short-fibre-reinforced concrete," Magazine of Concrete Research, vol. 59, no. 8, pp. 567-574, 2007.

[19] F. Altun, T. Haktanir, and K. Ari, "Effects of steel fiber addition on mechanical properties of concrete and RC beams," Construction and Building Materials, vol. 21, no. 3, pp. 654-661, 2007.

[20] A. Sivakumar and M. Santhanam, "Mechanical properties of high strength concrete reinforced with metallic and nonmetallic fibres," Cement and Concrete Composites, vol. 29, no. 8, pp. 603-608, 2007.

[21] E. A. Avallone and T. Baumeister III, Marks' Standard Handbook for Mechanical Engineers, McGraw-Hill, London, UK, 1996. 

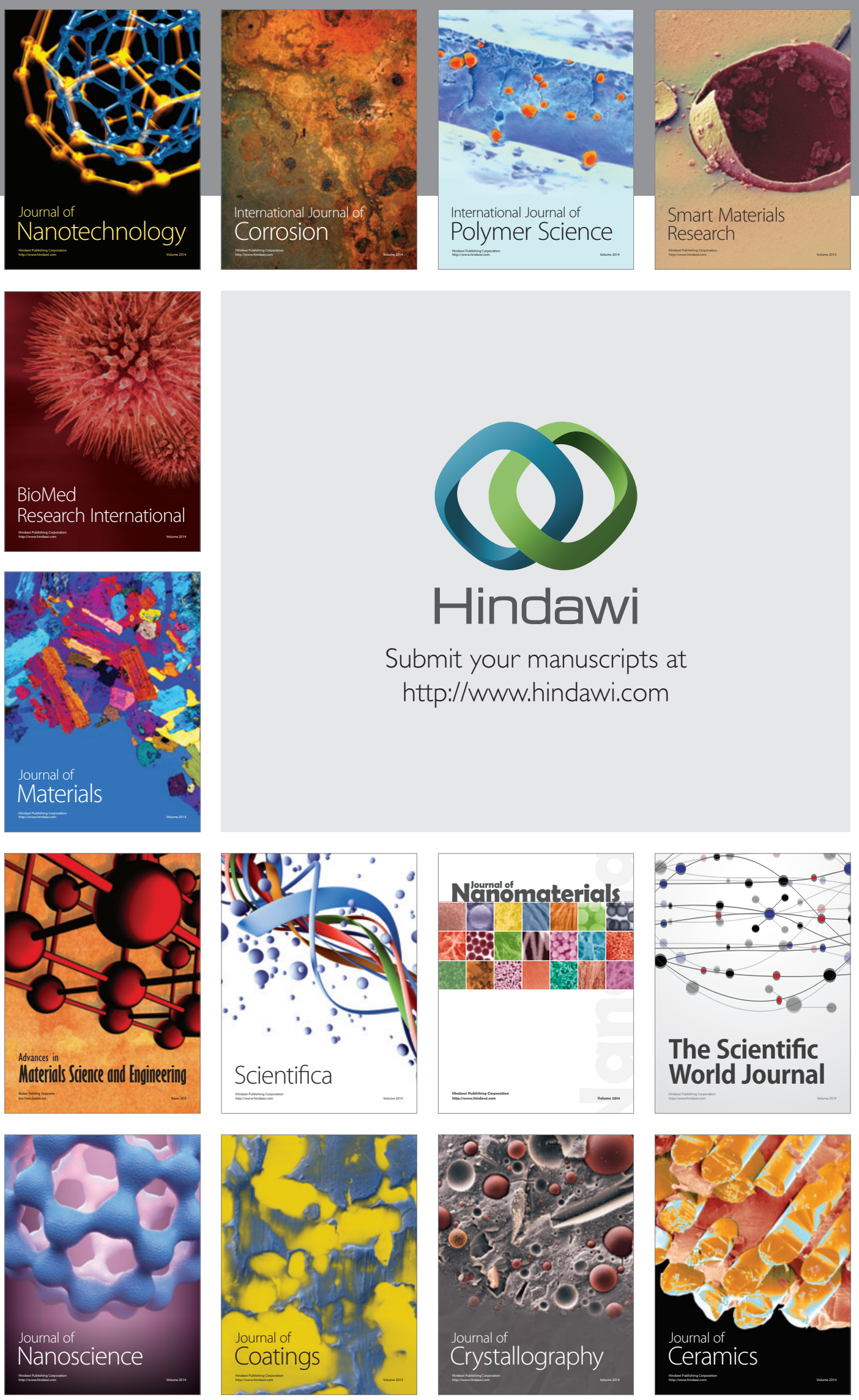

The Scientific World Journal

Submit your manuscripts at

http://www.hindawi.com

\section{World Journal}

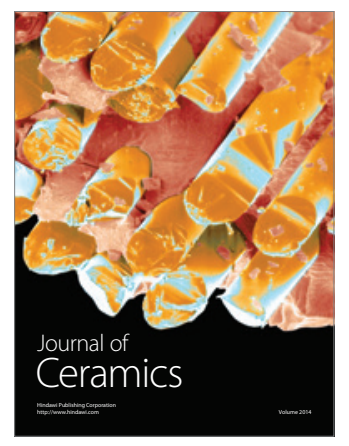

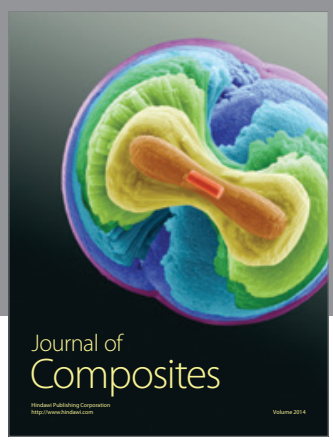
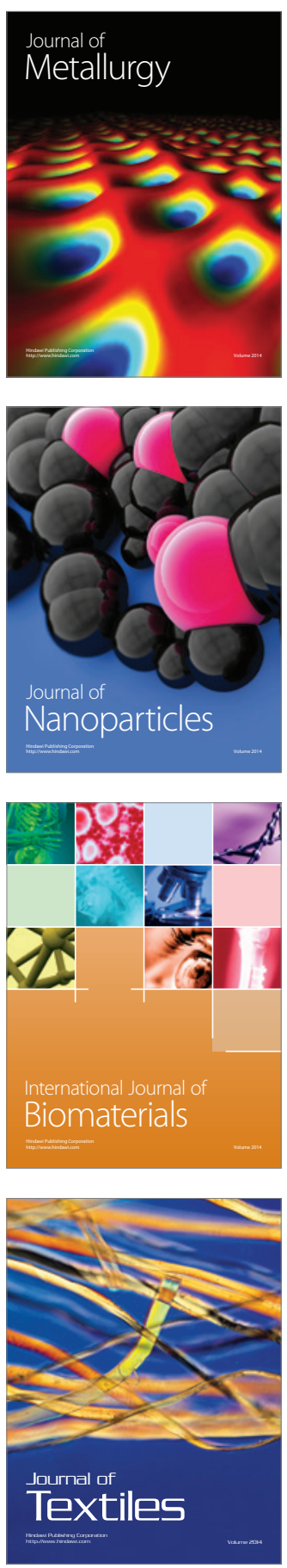